\title{
Pre-Scaling up of In Situ Moisture Conservation Techniques on Maize (Zea mays L.) yield in Dugda District
}

\author{
Dulo Husen* Zelalem Shalemew Ayub Jelde Anbase Ambosa Tesfaye Gemechu \\ Oromia Agricultural Research Institute,Adami Tulu Agricultural Research Center,P.O.Box 35, Batu,Ethiopia
}

\begin{abstract}
The activity was conducted during 2019 cropping season in Dugda District of Tepho Choroke Kebele. The objective was to scale up the selected in situ moisture conservation structures with maize crop (Tied ridge and furrow closed at both ends), improved farmers' knowledge and skills on application of improved technology through training and analyzed cost benefit of the structures. Five FREG groups were established in Tepho Choroke kebele of Dugda District. The total number FREG members were hold 30 male and 10 female farmers. A total of 130 farmers, 2 DAs, 4 SMS and 16 others were participated on the training respectively. The mean yield obtained from tied ridge and furrow closed at both ends were 99.41 and $86.74 \mathrm{~kg} \mathrm{ha}^{-1}$, respectively and sold $850 \mathrm{Birr}_{\mathrm{Qt}}{ }^{-1}$ at the current price. The net benefit obtained from tied ridge and furrow closed at both ends were 56,230 and 45,194-Birr ha ${ }^{-1}$, respectively. This implied that, the profit obtained from tied ridge was much better than furrow closed at both ends. This structure is much better in increasing yield and crop residue of maize. In addition, the total estimated profit obtained from furrow closed at both end are much better than the usual farmers practice. This also implied that in situ moisture conservation structure (tied ridge and furrow closed at both ends) are more economical and better if it is more scaled up in the study area and similar agro ecologies. Extension worker and Woreda Agricultural Bureau should have given attention to popularized and scaling up this technology to overcome problem of moisture deficit and food insecurity and improve agricultural production in the study area and similar agro ecologies.
\end{abstract}

Keywords: FREG, Furrow closed at end, Moisture deficit, Net benefit, Tied ridge

DOI: $10.7176 /$ CER/12-11-02

Publication date: November $30^{\text {th }} 2020$

\section{Introduction}

Ethiopian semi-arid and arid areas are experiencing low crop yield due to a combination of biophysical problems (Gicheru, 2002; Gitau, 2004). Low agricultural productivity in semi-arid region is not only due to land degradation, but also due to moisture deficit (Gebreegziabher et al., 2009). Moisture stress is a prolonged period of short precipitation resulting to water deficiencies and lack of soil moisture to support crop production (Solh and van Ginkel, 2014). Since rainfall is seasonal and erratic in dry lands of Ethiopia, there is moisture stress limiting the productivity of rain fed agriculture in the moisture stress areas (Haregeweyn et al., 2005). A study by Mekuria and Waddington (2004) noted the moisture stress being the major limitation to crops yield in cereal based cropping systems in Eastern and Southern Africa.

In East Shewa of Ethiopia, high moisture deficit is the primary problem that is highly constrains the productivity of farmers of the District (priority problems raised by farmers). In moisture scant environments like Central Rift valley in generally, particularly in Dugda District crop would face shortage of moisture available in the soil throughout the growing season. In Dugda district, there is an uneven distribution, late start and early finish of rainfall. In addition, the distribution of rainfall is not sufficient to sustain crop growth and development in the study area. The moisture deficit in the study area leading to low crop production and productivity. The major problem in this study area is unavailability of in situ moisture conservation techniques (Fikirneh Negash, Fiseha Tadesse, Megersa Handabo, Shimelis Gizachew, Tilahun Firomsa, and Abreham Feyissa, 2016).

Maize is the potential and staple food crop in Dugda district of Tepho Chore Kebele. In general, food deficit in the whole country, particularly in the moisture stress areas is increasing mainly due to drought (Kidane and Abuhay, 2000). The average annual rainfall recorded in most of meteorological stations in the Central Rift Valley (CRV) is well above $700 \mathrm{~mm} \mathrm{yr}^{-1}$ (Jansen et al (2009). In theory, this amount would be sufficient to grow crops, yet large areas do not achieve food self-sufficiency. The underlying reason for low crop yields might be that a high proportion of the rainfall is not available to the crop, because of excessive surface runoff and unproductive soil evaporation and erratic rainfall during the cropping season.

Accordingly, crop frequently suffers from moisture stress at some stage during its growth period with the ultimate result of reduced yield from their farmland because of shortage or uneven distribution of rainfall and absence conserving surface runoff within the catchment. This calls to design and scaling up in-situ moisture conservation techniques that have better role in sustaining crop production. Therefore, planting crops using in situ moisture conservation reduces problems of soil moisture stress by reducing runoff through increased infiltration and storage of water in the soil profile, the onset and occurrence of severe water stress is delayed thereby buffering the crop against damage caused by water deficits during dry periods (Nyamadzawo et al., 2013). 
In these regard, using tied ridge and furrow closed at both end are some of the methods that contribute to mitigate soil moisture deficit and enhance maize productivity in semi arid and arid areas. Currently there is no sufficient research works on scaling up in situ moisture conservation techniques on improving maize yield in Dugda District. Hence, the use of in situ moisture conservation structure is critically important to increase crop yield and improve food security. The two selected in situ moisture conservation structures were gave a significant yield improved over the surrounding the famers' practice in the study area. Therefore, the objectives of the experiment was to scale up the selected two in situ moisture conservation structures (Tied ridge and furrow closed at both ends), improved farmers' knowledge and skills on application of improved technology through training and analyzed cost benefit of the structures for further farmers used in the study area and similar agro ecology.

\section{Materials and Methods}

Description of study area

The field experiment was conducted at Dugda District, which is found in East Shewa zone of Oromia National Regional State. The Capital town of the district is Meki, which is located at a distance of 140 and $88 \mathrm{~km}$ from Addis Ababa and Adama respectively. Geographically, it situated in the central rift valley between $8^{\circ} 02^{\circ} 59^{\prime \prime} \mathrm{N}$ latitude and 38 $43^{\prime} 59^{\prime \prime}$ E longitude respectively. Its elevation is 1600 masl. According to the climatic data collected in 2019 from Adami Tulu Agricultural Researcher Center, the total annual rainfall of the area is $795.4 \mathrm{~mm}$ and minimum and maximum temperature is $13.6^{\circ} \mathrm{C}$ and $29.2^{\circ} \mathrm{C}$ respectively.

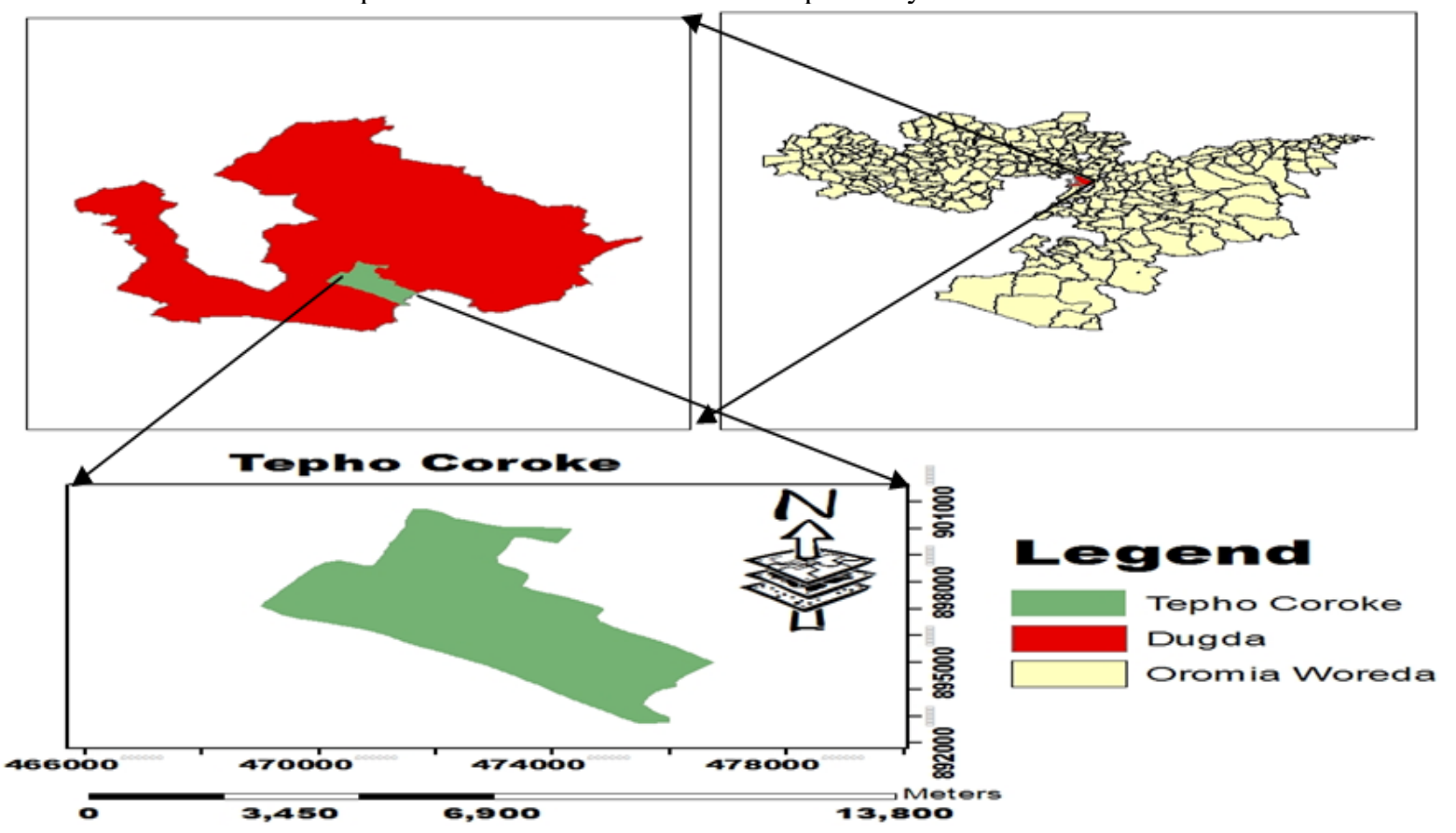

Figure 1: Map of study area

Site and Farmer selection and In-situ moisture conservation

The experiment was conducted at Tepho Chore kebele of Dugda district on five farmers farmland, to pre scaling up of the selected (Tied ridge and Furrow closed at both ends) in situ moisture conservation structures. Tepho Choroke kebele and farmers were selected purposively collaboration with district Agricultural experts and Development Agents (DAs). A total of five farmers were selected and formed in cluster. The farm size selected for each farmer was $100 \mathrm{~m}^{*} 100 \mathrm{~m}\left(10,000 \mathrm{~m}^{2}\right)$. Totally, five hectares $(5 \mathrm{ha})$ of land were selected to conduct the experiment. Land preparation was done before construction of in-situ moisture conservation structures on field. Two in situ moisture conservation structures (ridge furrow closed at end and tied ridge) were prepared by labor and used for demonstration in the study area. Cost benefit analyzed at the end of experiment. The roles and responsibilities between ATARC and farmers were signed before conducting of the experiment.

\section{Planting materials, fertilizer used and management}

The BH-540 maize variety was used as testing crop. The recommended seed rate, such that $25 \mathrm{~kg} / \mathrm{ha}$ of $\mathrm{BH}-540$ maize variety was used. The recommended fertilizer rate applied for the maize crop. Half of the rate of UREA and the full rate of the DAP fertilizers were applied at the time of sowing respectively. The second half of the UREA fertilizer was applied 30-40 days after planting. All necessary field managements starting from the land preparation, planting, structure preparation, fertilizer application, weeding, chemical spray and harvesting was undertaken 
collaboration with Adami Tulu Agricultural Research Center.

\section{Economic evaluation}

The total costs required for the experiments were recorded. In addition, total revenues obtained from the experiments were recorded. The calculations were done by converting the parameters per hectare. The recorded grain yield and crop residues were converted to current market price. Then, the profit obtained from the experiment was calculated by subtracting total cost from total revenue. This showed in Eq.1:

$$
\text { Profit }=\mathrm{TR}-\mathrm{TC}
$$

Where, $\mathrm{TR}=$ Total Revenue and $\mathrm{TC}=$ Total Cost $($ Total fixed costs + Total Variable costs $)$

\section{Data analysis}

The grain and economic data were collected using data collection sheet. Simple financial analysis was employed to analyze the costs required for the experiment and the net benefit gained from the production of each in situ moisture conservation structures. All costs required for the experiments and revenue obtained from experiments were recorded and subjected to analysis. The organized data was entered into Microsoft excel and simple descriptive analysis was undertaken and results were presented using tables.

\section{Results and Discussions}

\section{Farmers Selection and FREG establishment}

From the Dugda district, Tepho Choroke kebele was selected for conducting an experiment. The selected farmers were organized under Farmers Research Extension Group (FREG). The FREG members were selected purposively with Agricultural expert and Development agent (DA) with the criteria of those of who had commitment to implement the technology, interest and transferred knowledge obtained from training and field to adjacent farmers. The total numbers of FREG members were hold 30 male and 10 female farmers participated in the project and formed in five FREG group. The total of established FREG members had $75 \%$ of male and $25 \%$ female farmers (Table 1). From each FREG members, as hosting farmer, one directly benefited farmer was selected based on his willingness, commitment and interest.

Table 1: FREG establishment and number of FREG

\begin{tabular}{cccccc}
\hline \multirow{2}{*}{ Nistrict } & \multirow{2}{*}{ Kebele } & \multirow{2}{*}{$\begin{array}{c}\text { FREG } \\
\text { Established }\end{array}$} & & \multicolumn{2}{c}{ Number of FREG } \\
\cline { 3 - 6 } & Tepho Choroke & 5 & 30 & 10 & 40 \\
\hline Dugda & Total & $\mathbf{5}$ & $\mathbf{3 0}$ & $\mathbf{1 0}$ & $\mathbf{4 0}$ \\
\hline
\end{tabular}

\section{Capacity development \\ Training}

Training was organized before imposing any experiment on farmers' field. Totally 95 male and 31 female farmers, 1 female and male DAs, 4 male and no female SMS and 15 male and 1 female others were participated on the training respectively (Table 2 and Figure 2). The title of training is on the concepts of rainwater harvesting, it's importance on increasing yield in moisture deficit area and its effect on yield reduction if it is not prepared. Training was organized and given to stakeholder on the objectives and target of the activities to meet specific gaps on the experiment in the implementation of the activities. All FREG members were participated on training to obtain theoretical concept. Farmers, DAs and experts were attended and became aware on the in situ moisture conservation technologies. 


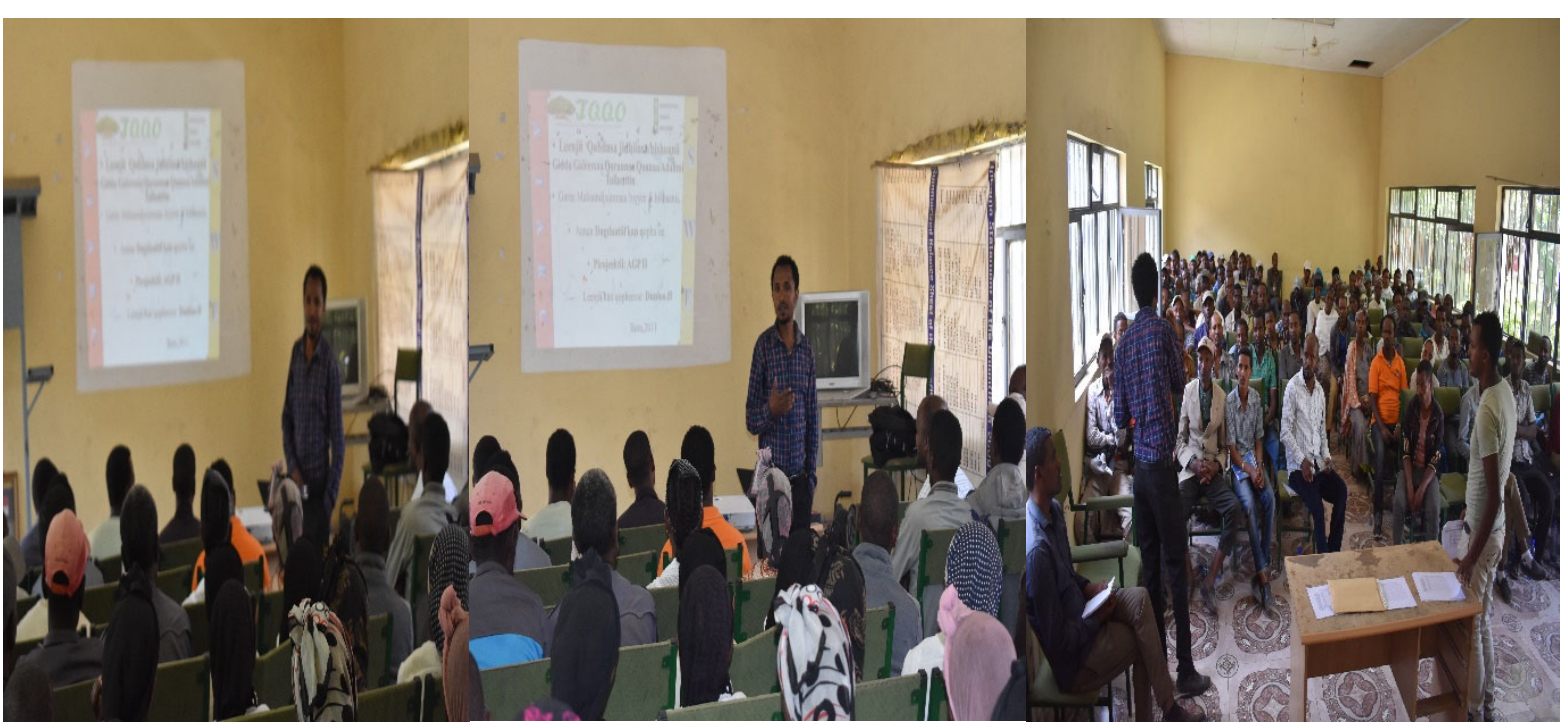

Figure 2: Introductory training to Farmers, DAs, SMS and others participants

Table 2: Number of farmers, DAs, SMS and others participated on the training

\begin{tabular}{|c|c|c|c|c|c|c|c|c|c|c|c|c|c|}
\hline \multirow{2}{*}{ District } & \multirow{2}{*}{ Kebele } & \multicolumn{3}{|c|}{ Farmers } & \multicolumn{3}{|l|}{ DAs } & \multicolumn{3}{|l|}{ SMS } & \multicolumn{3}{|c|}{ Others } \\
\hline & & Men & Women & Total & Men & Women & Total & Men & women & Total & Men & women & Total \\
\hline Dugda & $\begin{array}{l}\text { Tepho } \\
\text { Choroke }\end{array}$ & 95 & 35 & 130 & 1 & 1 & 2 & 4 & 0 & 4 & 15 & 1 & 16 \\
\hline Total & & 95 & 35 & 130 & 1 & 1 & 2 & 4 & $\mathbf{0}$ & 4 & 15 & 1 & 16 \\
\hline
\end{tabular}

Grain yield obtained from selected in situ moisture conservation structure

Table 3: Mean yield of maize obtained from tied ridge and furrow closed at both ends per hectare

\begin{tabular}{ll}
\hline Selected treatments & Yield $\left(\mathrm{Qtha}^{-1}\right)$ \\
\hline Tied Ridge & 99.41 \\
Furrow closed at both ends & 86.74 \\
\hline
\end{tabular}

The mean yield obtained from tied ridge and furrow closed at both ends were 99.41 and 86.74 Qtha ${ }^{-1}$ respectively (Table 3). The mean yield from tied ridge was better than furrow closed at both ends in the study area. The higher grain yield of maize recorded from planting on the tied ridge might be attributed to the higher water harvesting and retain more moisture when compared to the furrow closed at both ends in the study area. In addition, in tied ridge, moisture might be somewhat uniformly conserved and distributed within furrow when compared to the furrow closed at both ends. However, mean yield obtained from furrow closed at both ends were better than without conservation structures (flat bed) and this implied that, it conserve more moisture when you compare with neighboring farmer yield (used neighboring yield as check plot). The farmers also confirmed that this yield was better than what they have been obtained so far. The seeds, which were supplied with adequate moisture, did mature well to have heavier seed weight. This result agreed with Georgis and Takele 2000 reported, who stated that tied ridges have been found to be very efficient in storing the rainwater, which has resulted in substantial grain yield increase in some of the major dry land crops such as sorghum, maize, wheat, and mung beans in Ethiopia.

In addition, it attributed to the greater infiltration and storage of water in soil; which gives plants ample time to take up the stored water. This is apparently due to the moisture conserving benefits of this technology being critical in drier areas (kassie et al., 2007). In addition, in-situ water harvesting can improved crop yield and have resulted in positive effects on moisture conservation and agricultural productivity (Alamu and Kidane, 2014) and it aligned with this result. This finding agrees with many researchers Heluf, (2003), Gebreyesus (2004), and Taye and Yifru (2010) had reported the importance of tied ridge is increasing crop yield by increasing the time for the water to penetrate into the soil.

Generally, the experiment results indicated that maize yield was affected by selected in situ moisture conservation practices. Consequently, the significant maize yield increment resulted from tied ridge and furrow closed at both end of structures. Tied ridge and furrow closed at both ends is an effective measure in storing moisture.

\section{Yield Advantage}

$$
\text { Yield advantage }(\%)=\frac{\text { yield obtained from Tied ridge }- \text { yield obtained from } \mathrm{FCE}}{\text { yield obtained from furrow closed at both End(FCE) }} \times 100 \text { Eq. } 2
$$




$$
\text { Yield advantage }(\%)=\frac{99.41-86.74}{86.74} \times 100=14.61
$$

Yield advantage obtained from tied ridge was $14.61 \%$ than furrow closed at both ends. This implies that tied ridge conserved more rainwater and rainfall was uniformly distributed in the structure than furrow closed at both ends. However, the furrow closed at both ends also much better than flat bed (control). This result agreed with that of Araya and Stroosnijder (2010) and Walker et al. (2005), who stated that single interventions through water conservation could improve crop yield by up to $50 \%$ in arid and semi- arid regions of sub-Saharan Africa. In addition, Husen, D. and Shalemew, Z. (2020), who stated that the grain yield advantage of 45.5\% and 30.68\% were obtained from, tied ridge and furrow closed at both end respectively over the farmers' practice in Dudga district of Ethiopia. Similarly, Barron and Okwach (2005) showed that the rainwater harvesting technique increased yield by about $70 \%$ in semi-arid Kenya. Hence, practicing in situ rainwater harvesting structures is imperative and significance difference in grain yield.

\section{Financial Analysis}

Table 4: Estimated summary cost required for the tied ridge and furrow closed at both ends/ha

\begin{tabular}{lll}
\hline Description & Tied Ridge/ha & Furrow Closed at both ends/ha \\
\cline { 2 - 3 } & Sub-total (birr) & Sub-total(birr) \\
\hline Total Fixed Costs(TFC) & & \\
\hline Land purchase cost & 4,000 & 4,000 \\
\hline Total Variable Costs(TVC) & \\
\hline Labor, necessary payment and transport cost & 25,500 & 24,667 \\
Agricultural Input(seed, fertilizer and chemical) & 4,170 & 4,170 \\
Land preparation cost & 3,800 & 3,800 \\
\hline Total Costs(TC) & $\mathbf{3 7 , 4 7 0}$ & $\mathbf{3 6 , 6 3 7}$ \\
\hline
\end{tabular}

The total estimated summary costs required for the tied ridge and furrow closed at both end were 37,470 and 36,637 ETH.Birr ha ${ }^{-1}$, respectively. The tied ridge and furrow closed at both ends structures were labor intensive, thus it required more cost.

\section{Revenue obtained for the experiment}

Table 5: Estimated summary Revenue obtained from the tied ridge and furrow closed at both end/ha

\begin{tabular}{lll}
\hline Descriptions & Tied Ridge/ha & Furrow Closed at both ends/ha \\
\cline { 2 - 3 } & Total(birr) & Total(birr) \\
\hline Yield & 84,500 & 73,731 \\
Crop residual & 9,200 & 8,100 \\
\hline Total Revenue(TR) & $\mathbf{9 3 , 7 0 0}$ & $\mathbf{8 1 , 8 3 1}$ \\
\hline
\end{tabular}

From tied ridge, 99.41 $\mathrm{Qt} \mathrm{ha}^{-1}$ of maize obtained and sold 850-Birr $\mathrm{Qt}^{-1}$ at the current. In addition, from furrow closed at end, 86.74 $\mathrm{Qt} \mathrm{ha}^{-1}$ of maize obtained and sold 850-Birr $\mathrm{Qt}^{-1}$ at the current. The total estimated profit obtained from the tied ridge and furrow closed at both was 93,700 and 81,831 ETH. Birr ha ${ }^{-1}$ respectively (Table 5). The tied ridge was provided a better crop residual than furrow closed at both ends, and the revenue of yield and crop residual obtained from tied ridge was better than furrow closed at both ends. This implies that the tied ridge was providing greater revenue than furrow closed at both ends.

\section{Net Befits}

Net Benefit obtained from the experiment is calculated by using eq. 1

Net Benefit obtained from tied ridge per hectare $=$ Total revenue/ha- total cost $/$ ha

Net Benefit obtained from tied ridge per hectare $=93,700-37,470$ birr ha $^{-1}=\mathbf{5 6 , 2 3 0}$ Birr ha $^{-1}$

Net Benefit obtained from furrow closed at both ends per hectare $=$ Total revenue- Total cost

Net Benefit obtained from furrow closed at both ends per hectare $=81,831-36,637$ Birr ha $^{-1}=\mathbf{4 5 , 1 9 4}$ Birr ha $^{-1}$

The total profit obtained from tied ridge and furrow closed at both ends were 56,230 and 45,194-Birr ha ${ }^{-1}$ respectively. This implies that, the profit obtained from tied ridge was much better than furrow closed at both ends. This structure is much better in increasing yield and crop residues of maize. In addition, total estimated profit obtained from furrow closed at both ends was better. In generally, the two structures were better in the study in providing better profit and more economical.

\section{Challenges encountered and possible solutions given}

Maize was attached by Stalk Borer (spodoptera frugiperda), but it was easily controlled by spraying chemical. However, in-situ moisture conservation was not implemented in whole area of farmland; because of lack of equal awareness between famers, lack of budget or delay of budget, area is large and structure preparation is labor intensive. On the other hand, samples of insitu moisture conservation structures were prepared on the farmer field; 
and some what created the awarness in order to compare the performances of crop on selected in situ moisture conservation structures with neighbouring flat bed (without conservation) parctice by themselves. The field daay was not prepared because shortage of budget and the structures were not prepared on the whole farm land.

\section{Conclusions and Recommendations}

The low crop productivity in the country particularly in the study area is due to low soil moisture, erratic and poorly distributed rainfall. This calls to design effective and efficient in-situ moisture conservation strategies, which have better role in sustaining crop production. The effect of selected in-situ moisture conservation structures (tied ridge and furrow closed at both ends) were better in terms of maize production. The tied ridge structure gave more mean grain yield of maize than furrow closed at both ends. The furrow closed at both end also better in terms of mean grain yield. Tied ridge and furrow closed at both ends showed a promising result on maize grain yield.

Therefore, tied ridge and furrow closed at both ends were more economical and it is best for mitigation of low moisture stress. As future recommendations, it needs to scale up this technology more in moisture deficit area and disseminate the results of the present to end user and more focus on awareness creation.

\section{Exit Strategies}

Agricultural Extension worker and district agricultural bureau should have given great attention to popularized and scaling up in situ moisture conservation technologies. In addition, the theoretical and practical training should be provided to farmers on in-moisture conservation and other should be learn from them and the close follow up and monitoring should be done as to be reach to other farmers

\section{Acknowledgements}

The authors would like to thanks Agricultural Growth Program II (AGP-II) for financing the project. We would like to express our appreciation to all staff of Soil and Water Engineering and Agricultural Extension Research Team and AGP-II focal person of Adami Tulu Agricultural Research Center for their active participation in conducting this experiment. In addition, we would like to grateful to Dugda district agricultural and natural resources bureau for helped from site and framers selection up to accomplishing the experiment. Lastly, but not least, we sincerely thanks the farmers of Tepho Coroke kebele, who allocated their land for the experiment.

\section{References}

Alemu B and Kidane D (2014). The Implication of Integrated Watershed Management for Rehabilitation of Degraded Lands: Case Study of Ethiopian Highlands. J Agric Biodivers Res, 3(6): 78-90.

Barron J, Okwach G (2005). Run-off water harvesting for dry spell mitigation in maize (Zea mays L.): results from on-farm research in semi-arid Kenya. Agricultural Water Management 74, 1-21.

Fikirneh Negash, Fiseha Tadesse, Megersa Handabo, Shimelis Gizachew, Tilahun Firomsa, and Abreham Feyissa (2016). Participatory Agricultural Production Constraint Analysis in Oromia: A Guiding Tool for Strategic Research and Development Interventions; Case Study in East and North Shoa, Oromia Regional State (un published).

Gebreegziabher, T., Nyssen, J., Govaerts, B., Fekadu, G., Mintesinot, B., Mitiku, H., and Deckers, J (2009). Contour furrows for in situ soil and water conservation, Tigray, Northern Ethiopia. Soil and Tillage Research, $103,257-264$.

Gebreyesus B. T (2004). Tied Ridging as In-situ Rainwater Harvesting Methods for Improving Sorghum Yield at Abergelle Area, Tigray Regional State. An MSc. Thesis submitted to Haremaya University.

Georgis K, Takele A (2000). Conservation farming technologies for sustaining crop production in semi-arid areas of Ethiopia. In Conservation Tillage for Dryland Farming. Technological options and experiences in Eastern and Southern Africa, eds. E.K. Biamah; J. Rockstrom; G.E. Okwach. RELMA, Workshop Report No. 3, 142147.

Gicheru P.T (2002). The effect of different soil management practices on crust formation, soil moisture conservation and crop growth in Machang'a area, Mbeere District, Kenya. Ph.D Thesis. University of Nairobi, Kenya.

Gitau A.N (2004) .Mechanical behavior of hard setting Luvisol soil. Ph.D Thesis, University of Nairobi, Kenya.

Haregeweyn et al., J. Poesen, G. Verstraeten, J. De Vente, G. Govers, S. Deckers, J. Moeyersons (2005). Specific sediment yield in Tigray, Northern Ethiopia: Assessment and semi-quantitative modeling. Geomorphology $69,315-331$.

Heluf G. (2003). Grain yield response of sorghum (sorghum bicolor) to tied ridges and planting methods on Entisols and Vertisols of Alemaya area, Eastern Ethiopian highlands journal of agriculture and rural development in the Tropics and Subtropics 104(2):113-128.

Husen, D. and Shalemew, Z (20200.Effects of In-situ Moisture Conservation Techniques on Maize(Zea Mays) Yield and Yield Components(Moisture Deficit Area of Dugda woreda),International Journal of Agricultural 
and agribusiness 7(1):17-23.

Jensen, J.R., Berhard, R.H., Hasen, S., Mulching Donagh, J., Moberg, J.P., Nielsen, N.E., and Nordbo, E (2003). Productivity in maize based cropping systems under various soil water management strategies in a semi-arid, alfisol environment in East Africa. Agricultural Water Management, 59, 217-237.

Kassie, M. and Holden, S (2007). Share cropping efficiency in Ethiopia: threats of eviction and kinship. Agricultural Economics 37: 179 -188.

Kidane Georgis, and Abuhay Takele (2000). A Manual for Semi-arid Areas of Ethiopia: Resource Base, Constraints and Improved Technologies for Sustainable Agricultural Production, mimeo. EARO, Addis Ababa, Ethiopia.

Mekuria, M. and Waddington, S. (2004) Institutional and Policy Support Is Essential to Promote the Adoption of Soil Fertility Technologies on Maize-Based Smallholder Farms in Southern Africa. Proceedings of the 4th International Crop Science Congress, Brisbane.

Nyamadzawo G, Wuta M, Nyamangara J, Gumbo D (2013). Opportunities for optimizing in field water harvesting to cope with changing climate in semiarid smallholder farming areas of Zimbabwe. Springer plus 2, 1-9

Solh, M., \& van Ginkel, M (2014). Drought preparedness and drought mitigation in the developing world's drylands. Weather and Climate Extremes, 3(1), 62-66.

Stroosnijder, L. and Araya, A (2010). Effects of Tied Ridges and Mulch on Barley (Hordeum vulgare) Rainwater Use Efficiency and Production in Northern Ethiopia. Agric. Water Manag., 97:841-847

Taye Belachew and Yifru Abera (2010). Response of maize (Zea mays L.) to tied ridges and planting methods at Goro, Southeastern Ethiopia. American-Eurasian Journals if Agronomy, 3(1): 21-24 